\title{
Effects of dietary lipid level on growth, survival and body composition of Brazilian codling (Urophycis brasiliensis Kaup, 1858)
}

\author{
Efecto de los niveles de lípidos dietarios sobre el crecimiento, supervivencia y composición \\ proximal de la brótola (Urophycis brasiliensis Kaup, 1858) \\ Sergio N. Bolasina ${ }^{1}$ and Jorge L. Fenucci ${ }^{1,2}$ \\ ${ }^{1}$ Universidad Nacional de Mar del Plata, Facultad de Ciencias Exactas y Naturales Funes 3350 (7600), \\ Mar del Plata, Buenos Aires, Argentina \\ ${ }^{2}$ Consejo Nacional de Investigaciones Científicas y Técnicas (CONICET), Argentina \\ sbolasina@hotmail.com
}

\begin{abstract}
Resumen.- El objetivo del presente trabajo es determinar la influencia de los niveles de lípidos en dietas formuladas sobre el crecimiento, supervivencia, índice hepatosomático (HSI) y composición proximal del músculo e hígado de la brótola.

Se fabricaron tres dietas diferentes (40\% proteína cruda) con $3 \%$, $6 \%$ y $10 \%$ de aceite de pescado, obteniendo un $5 \%$, $8 \%$ y $11 \%$ de lípidos crudos, respectivamente. La tasa diaria de alimentación fue del 3\%. Al finalizar el experimento a los 40 días, los animales fueron pesados y se tomaron muestras de tejido muscular y hepático.

La mayor tasa de crecimiento en peso se obtuvo en el grupo alimentado con los niveles más bajos de lípidos. Se observaron diferencias significativas $(P<0,05)$ en crecimiento, supervivencia e índice hepatosomático entre los grupos. En los animales alimentados con altos niveles de lípidos se encontraron hígados de mayor tamaño y color más pálido. El contenido de proteína cruda, lípidos y humedad del tejido hepático en este grupo fue significativamente diferente $(P<0,05)$ al compararlo con los otros dos tratamientos; siendo el contenido de proteína en músculo significativamente menor $(P<0,05)$. No se encontraron diferencias significativas $(P<0,05)$ al comparar entre tratamientos los contenidos de cenizas en ambos órganos y en los niveles de lípidos y humedad en músculo. Se concluye que los niveles mas adecuados de lípidos en la formulación de dietas para la brótola podrían estar en torno al 5\%.
\end{abstract}

Palabras clave: Nutrición, índice hepatosomático, formulación de dietas

\section{Introduction}

Brazilian codling, Urophysis brasiliensis, is a demersal fish that inhabits shallow coastal waters between Rio de

\begin{abstract}
The aim of this study was to determine the influence of lipid level in formulated feeds on growth, survival, hepatosomatic index (HSI) and proximate composition of liver and muscle in Brazilian codling.

Three different experimental diets ( $40 \%$ crude protein) were made using $3 \%$, $6 \%$ and $10 \%$ of fish oil, obtaining $5 \%$, $8 \%$ and $11 \%$ of crude lipid, respectively. Daily feeding rate was kept at $3 \%$ of fish body weight. At the end of the 40 day trial, the fish were weighed and samples from muscle and liver were taken.

The highest weight gain was obtained at the lowest dietary lipid level. The lowest survival rate and greater HSI was found in the group fed with the highest lipid level. Significant differences $(P<0.05)$ in terms of growth, survival and hepatosomatic index were observed between the groups. The group with higher lipid levels showed larger pale livers. Liver protein, lipid and water content in this group were significantly different $(P<0.05)$ to those of fish fed the other diets. Muscle protein content was significantly lower $(P<0.05)$ in fish fed the highest lipid level compared with the other treatments. No significant differences $(P<0.05)$ in ash content in both organs and in lipid and water content in the muscle were found among treatments.

It is concluded that the more suitable dietary lipid levels for Brazilian codling growth and survival might be around $5 \%$.
\end{abstract}

Key words: Nutrition, hepatosomatic index, diet formulation
Janeiro State, Brazil (21ํ 30'S) and San Matías Gulf, Argentina $\left(41^{\circ} 10^{\prime} \mathrm{S}\right)$. Some studies on nutrition and stress in this fish were conducted previously with the 
purpose of evaluating its culture potential (Bolasina \& Fenucci 1999, 2005).

It is known that growth and chemical composition of fish can be influenced by dietary manipulation (Shearer 1994). Many studies have analyzed the effects of dietary lipid level in marine fish, like red drum, Sciaenops ocellatus, (Williams \& Robinson 1988, Craig et al. 1999), gilthead seabream, Sparus aurata, (Kalogeropoulos et al. 1992, Robaina et al. 1998), turbot, Scophthalmus maximus (Sæther \& Jobling 2001), cobia, Rachycentron canadum (Wang et al. 2005) and Atlantic cod, Gadus morhua, (Jobling 1988, Jobling et al. 1991, Couture et al. 1998, Grant et al. 1998, Morais et al. 2001).

Lipid inclusion in diets may not only improve growth and nutritional status, it also may increase food palatability (Smith 1980). The artificial rearing of cod has been associated with the occurrence of enlarged fatty livers (Jobling, 1988; Jobling et al. 1991, Grant et al. 1998, Morais et al. 2001).

Therefore, the aim of this study was to determine the influence of the lipid level in artificial diets on growth, survival, hepatosomatic index (HSI) and proximate composition of liver and muscle from Brazilian codling.

\section{Materials and methods}

Experimental fish were caught from Mar del Plata coast $\left(38^{\circ} 00^{\prime} \mathrm{S}\right)$ with a trawling net. Afterwards they were transported to J.J. Nágera Research Station and placed in a $2000 \mathrm{l}$ fiberglass tank for 20 days. During the acclimatization period, fishes $(\mathrm{n}=36)$ were fed daily with minced squid mantle. Initial weight was $116 \pm$ $5.74 \mathrm{~g}$ (mean $\pm \mathrm{SD}$ ). After this period they were distributed into three replicated groups in $300 \mathrm{l}$ fiberglass tanks. Three different experimental diets ( $40 \%$ crude protein) were made (Table 1 ), with $3 \%, 6 \%$

Table 1

Ingredients and proximate composition (\% dry weight) of the $\operatorname{diets}^{1}$

Ingredientes y composición proximal (\% peso seco) de las dietas ${ }^{1}$

\begin{tabular}{|c|c|c|c|}
\hline Ingredient & diet $1(\%)$ & diet $2(\%)$ & diet $3(\%)$ \\
\hline Fish oil & 3 & 6 & 10 \\
\hline Fish meal & 55 & 55 & 55 \\
\hline Wheat starch & 20 & 20 & 20 \\
\hline Wheat bran & 8 & 5 & 1 \\
\hline Soybean meal & 7 & 7 & 7 \\
\hline Fish solubles & 2 & 2 & 2 \\
\hline Vitamin complex ${ }^{2}$ & 2 & 2 & 2 \\
\hline Wheat gluten & 3 & 3 & 3 \\
\hline Moisture & $5.33 \pm 0.54^{\mathrm{a}}$ & $4.95 \pm 0.40^{\mathrm{a}}$ & $4.67 \pm 0.57^{\mathrm{a}}$ \\
\hline Lipid & $5.40 \pm 1.04^{\mathrm{a}}$ & $8.15 \pm 0.63^{b}$ & $10.77 \pm 0.37^{\mathrm{c}}$ \\
\hline Protein & $42.89 \pm 0.33^{\mathrm{a}}$ & $42.59 \pm 0.38^{\mathrm{a}}$ & $42.34 \pm 0.27^{\mathrm{a}}$ \\
\hline Ash & $6.73 \pm 0.32^{\mathrm{a}}$ & $7.85 \pm 0.22^{a}$ & $10.13 \pm 0.46^{b}$ \\
\hline $\begin{array}{l}\text { Total energy } \\
\text { (kJ/100g of diet) }\end{array}$ & 1839.12 & 1928.61 & 2018.10 \\
\hline $\mathrm{P}:$ E ratio $(\mathrm{mg} / \mathrm{kJ})$ & 23.31 & 22.24 & 21.25 \\
\hline \multicolumn{4}{|c|}{$\begin{array}{l}{ }^{1} \text { Values in each row with the same superscripts are not significantly different }(\mathrm{P}<0.05) \text {. } \\
{ }^{2} \text { Composition }(\mathrm{g} / \mathrm{kg}) \text { : vitamin } \mathrm{D} 3,1.8 \mathrm{~g} \text {; thiamin, } 8.2 \mathrm{~g} \text {; riboflavin, } 7.8 \mathrm{~g} \text {; pyridoxine, } 10.7 \mathrm{~g} \text {; calcium } \\
\text { pantothenate, } 12.5 \mathrm{~g} \text {; biotin, } 12.5 \mathrm{~g} \text {; niacin, } 25 \mathrm{~g} \text {; folic acid, } 1.3 \mathrm{~g} \text {; cyanocobalamin, } 1 \mathrm{~g} \text {; ascorbic } \\
\text { acid, } 39.1 \mathrm{~g} \text {; menadione, } 1.7 \mathrm{~g} \text {. }\end{array}$} \\
\hline
\end{tabular}


and $10 \%$ of fish oil, respectively. Daily feeding rate was $3 \%$ of body weight. At the end of the 40 day trial, fish were weighed and samples of muscle and liver were taken randomly from five individuals per treatment. Water temperature during the feeding experiment was kept at $13.7 \pm 1.8^{\circ} \mathrm{C}$. Moisture content of the samples was determined after $48 \mathrm{~h}$ of drying in an oven at $65^{\circ} \mathrm{C}$. For the analysis of total protein and lipid content, the micro-Kjeldahl and Soxhlet methods were followed, respectively. Ash content was determined by dry ashing in a muffle furnace at $600^{\circ} \mathrm{C}$ overnight. Each analysis was conducted in triplicate.

A one-way analysis of variance (ANOVA) was performed to compare growth, hepatosomatic index and proximate analysis of muscle and liver from fish in the various treatments. Previously, Cochran's test was used for testing variance homocedasticity. Tukey's test was used for post hoc comparisons. For survival rates, the Chi-square test was applied.

\section{Results and discussion}

The comparison of proximate content in diets showed significant differences $(\mathrm{P}<0.05)$ in lipid and ash content, in both cases related with the amounts of fish oil used (Table 1).

The highest weight gain was obtained at the lowest dietary lipid level, comparison between groups showed significant differences $(\mathrm{P}<0.05)$ in the final weight and in weight gain (Table 2). Similar results were found in white seabass, Atractoscion nobilis (López et al. 2005). Survival rate and HSI were significantly lower in the fish fed diet 3 with the highest lipid content (Table 2). Fish fed diet 3 showed larger and pale livers different to those found in fish feeding the other two diets. The composition of livers dissected from the fish fed diet 3 , in terms of protein, lipid and moisture (Table 3) was significantly different $(P<0.05)$ from those obtained from fish feeding the other two diets. The increase of lipid content in liver is associated with the reduction of the water content. No significant differences were found in the composition of muscle from the 3 groups with the exception of protein which was significantly lower $(P<0.05)$ on fish fed diet 3.

Liver is the main storage tissue in Atlantic cod (Gadus morhua) (Jobling 1988) in terms of energy in contrast with salmonids in which muscle carries out this role. In the case of Brazilian codling the results obtained in this study indicate that the liver acted as a storage tissue in a similar way like Atlantic cod. Jobling et al. (1991) raised the question whether the use of dry, high energy, formulated feeds versus moist, low energy, natural prey influences the pattern of energy deposition. Thus, dry formulated diets increased lipid deposition in the liver and, therefore, the HSI, when compared to either wet diets or natural prey of similar composition. Morais et al. (2001), however, in a similar experiment did not find any significantly higher liver lipid content and increased HSI when high energy extruded diets were used.

Table 2

Initial $\left(\mathrm{W}_{0}\right)$ and final $\left(\mathrm{W}_{\mathrm{f}}\right)$ weights (mean $\left.\pm \mathrm{SD}, \mathrm{n}=36\right)$; weight gain $(\mathrm{WG})$; survival $(\mathrm{S})$ and hepatosomatic index (HSI) ${ }^{1}$

Peso inicial $\left(\mathrm{W}_{0}\right)$ y final $\left(\mathrm{W}_{\mathrm{f}}\right)$ (media \pm desviación estándar, $\left.\mathrm{n}=36\right)$; incremento en peso (WG), superivencia (S) e índice hepatosomático (HSI) ${ }^{1}$

\begin{tabular}{cccc}
\hline & Diet 1 & Diet 2 & Diet 3 \\
\hline $\mathrm{W}_{0}(\mathrm{~g})$ & $116.50 \pm 9.34^{\mathrm{a}}$ & $116.41 \pm 10.96^{\mathrm{a}}$ & $117.66 \pm 8.83^{\mathrm{a}}$ \\
$\mathrm{W}_{\mathrm{f}}(\mathrm{g})$ & $140.50 \pm 20.04^{\mathrm{a}}$ & $126.00 \pm 10.75^{\mathrm{b}}$ & $119.41 \pm 5.77^{\mathrm{c}}$ \\
$\mathrm{WG}^{\dagger}(\%)$ & $20.60 \pm 1.35^{\mathrm{a}}$ & $8.23 \pm 0.76^{\mathrm{b}}$ & $1.49 \pm 0.40^{\mathrm{c}}$ \\
$\mathrm{S}(\%)$ & $100^{\mathrm{a}}$ & $100^{\mathrm{a}}$ & $58.33^{\mathrm{b}}$ \\
$\mathrm{HSI}^{\ddagger}(\%)$ & $0.37 \pm 0.35^{\mathrm{a}}$ & $0.36 \pm 0.30^{\mathrm{a}}$ & $1.64 \pm 0.46^{\mathrm{b}}$ \\
\hline
\end{tabular}

${ }^{1}$ Values in each row with the same superscripts are not significantly different $(\mathrm{P}<0.05)$.

$\dagger \mathrm{WG}=[(\mathrm{Wf}-\mathrm{W} 0) / \mathrm{W} 0] \times 100$

$\ddagger$ HSI $=$ (liver weight $/$ total weight) $\times 100$ 
Table 3

Proximate analysis (mean \pm SD, $n=5$ ) of muscle and liver of fishes fed with three different diets ${ }^{1}$

Análisis proximal (media \pm desviación éstandar, $n=5$ ) del músculo e hígado de los peces alimentados con tres dietas diferentes ${ }^{1}$

\begin{tabular}{|c|c|c|c|c|}
\hline & $\begin{array}{c}\text { Protein } \\
\text { (\% dry weight) }\end{array}$ & $\begin{array}{c}\text { Lipid } \\
\text { (\% dry weight) }\end{array}$ & $\begin{array}{c}\text { Ash } \\
\text { (\% dry weight) }\end{array}$ & $\begin{array}{c}\text { Moisture } \\
\text { (\% wet weight) }\end{array}$ \\
\hline \multicolumn{5}{|l|}{ diet 1} \\
\hline liver & $34.22 \pm 1.15^{\mathrm{a}}$ & $17.55 \pm 1.43^{\mathrm{a}}$ & $3.40 \pm 0.36^{\mathrm{a}}$ & $90.14 \pm 2.08^{\mathrm{a}}$ \\
\hline muscle & $80.00 \pm 2.30^{\mathrm{a}}$ & $14.92 \pm 1.02^{\mathrm{a}}$ & $3.22 \pm 0.67^{\mathrm{a}}$ & $82.76 \pm 2.76^{\mathrm{a}}$ \\
\hline \multicolumn{5}{|l|}{ diet 2} \\
\hline liver & $32.34 \pm 1.20^{\mathrm{a}}$ & $16.72 \pm 1.41^{\mathrm{a}}$ & $3.34 \pm 0.58^{\mathrm{a}}$ & $68.93 \pm 1.87^{\mathrm{b}}$ \\
\hline muscle & $80.12 \pm 1.97^{\mathrm{a}}$ & $14.15 \pm 0.86^{\mathrm{a}}$ & $3.57 \pm 1.60^{\mathrm{a}}$ & $83.23 \pm 2.36^{\mathrm{a}}$ \\
\hline \multicolumn{5}{|l|}{ diet 3} \\
\hline liver & $30.09 \pm 1.76^{b}$ & $33.72 \pm 2.24^{b}$ & $3.36 \pm 0.72^{\mathrm{a}}$ & $44.52 \pm 2.60^{c}$ \\
\hline muscle & $76.02 \pm 2.04^{b}$ & $16.43 \pm 1.04^{\mathrm{a}}$ & $3.45 \pm 1.92^{\mathrm{a}}$ & $86.58 \pm 2.38^{\mathrm{a}}$ \\
\hline
\end{tabular}

${ }^{1}$ Values from each organ in each column with the same superscripts are not significantly different $(\mathrm{P}<0.05)$.

According to Jobling et al. (1999), the use of high energy diets is not suitable for Atlantic cod (Jobling et al. 1991), as all the amino acids contained in excess are deaminated and catabolized or used for lipid synthesis. Lipids in excess will be stored in the liver as triacylglycerides, enlarging its volume. In the case of the Brazilian codling, according to the results of the present study, the use of diets with low lipid content will prevent the formation of fatty livers. If the lipid content in the diets increase to $10 \%$ weight gain and survival will be affected and HSI and liver lipid content will be increased. In conclusion, dry diets can be used for the rearing of Brazilian codling if total lipid content is maintained around $5 \%$ to avoid the formation of fatty livers.

\section{Literature cited}

Bolasina SN \& JL Fenucci. 1999. Evaluación del reemplazo de harina de pescado por harina de carne en dietas secas y su efecto sobre el crecimiento en cuatro especies de peces costeros. Anales de Acuicultura Venezuela 1999: 58-63.

Bolasina SN \& JL Fenucci. 2005. Digestibilidad aparente de proteína cruda y lípidos en la brótola, Urophycis brasiliensis, utilizando reemplazos parciales de harina de soja y de carne en las dietas. Revista de Biología Marina y Oceanografía 40 (2):127-131.
Couture P, JD Dutil \& H Guderley. 1998. Biochemical correlates of growth and condition in juvenile Atlantic cod (Gadus morhua) from Newfoundland. Canadian. Journal of Aquatic Sciences 55: 1591-1598.

Craig SR, BS Washburn \& DM Gatlin III. 1999. Effects of dietary lipids on body composition and liver function in juvenile red drum, Sciaenops ocellatus. Fish Physiology and Biochemistry 21: 249-255.

Grant SM, JA Brown \& DL Boyce. 1998. Enlarged fatty livers of small juvenile cod (Gadus morhua): a comparison of laboratory cultured and wild juveniles. Journal of Fish Biology 52:1105-1114.

Jobling M. 1988. A review of the physiological and nutritional energetics of cod, Gadus morhua L., with particular reference to growth under farmed conditions. Aquaculture 70: 1-19.

Jobling M, R Knudsen, PS Pedersen \& J Dos Santos 1991. Effects of dietary composition and energy content on the nutritional energetics of cod, Gadus morhua. Aquaculture 92: 243- 257.

Kalogeropoulos N, MN Alexis \& J Henderson. 1992. Effects of dietary soybean and cod live oil levels on growth and body composition of gilthead bream (Sparus aurata). Aquaculture 104: 293-308. 
López L, AL Torres, E Durazo, M Drawbridge \& D Bureau. 2005. Effects of lipid on growth and feed utilization of white seabass (Atractoscion nobilis) fingerlings. Aquaculture 253: 557-563.

Morais S, J Gordon Bell, DA Robertson, WJ Roy \& PC Morris. 2001. Protein - lipid ratios in extruded diets for Atlantic cod Gadus morhua L.: effects on growth, feed utilization, muscle composition and liver histology. Aquaculture 203: 101-119.

Robaina L, MS Izquierdo, FJ Moyano, J Socorro, JM Vergara \& D Montero. 1998. Increase of the dietary $n-3$ / $n-6$ fatty acid ratio and addition of phosphorus improves liver histological alterations induced by feeding diets containing soybean meal to gilthead seabream, Sparus aurata. Aquaculture 161: 281-293.
Sæther BS \& M Jobling. 2001. Fat content in turbot feed: influence on feed intake, growth and body composition. Aquaculture Research 32(6): 451-458.

Shearer KD. 1994. Factors affecting the proximate composition of cultured fishes with emphasis on salmonids. Aquaculture 119: 63-88.

Smith RR. 1980. Nutritional bioenergetics. In: Fish feed technology. Rome, FAO/UNDP, Aquaculture Development and Coordination Programme, ADCP/REP/80/11: 21-27.

Wang J, Y Liu, L Tian, K Mai, Z Du, Y Wang \& H Yang. 2005. Effect of dietary lipid level on growth performance, lipid deposition, hepatic lipogenesis in juvenile cobia (Rachycentron canadum). Aquaculture 249: 439-447.

Williams CD \& EH Robinson. 1988. Response of red drum to various dietary levels of menhaden oil. Aquaculture 70: 107-120.

Recibido el 5 de junio de 2006 y aceptado el 31 de enero de 2007 